\title{
Pengaruh Budaya Organisasi, Komunikasi, dan Lingkungan Kerja Terhadap Kepuasan Kerja Karyawan pada Direktorat Jenderal Bimbingan Masyarakat Hindu Kementerian Agama Republik Indonesia
}

\author{
Andy ${ }^{1)}$ \\ Ida Ayu Made Sintya Dwi $S^{2)}$ \\ Universitas Buddhi Dharma \\ andy.kee9@gmail.com
}

\begin{abstract}
ABSTRAK
Penelitian ini adalah bertujuan untuk mengetahui seberapa jauh budaya organisasi, komunikasi, dan lingkungan kerja berpengaruh terhadap peningkatan kepuasan kerja pada Direktorat Jenderal Bimbingan Masyarakat Hindu Kementerian Agama Republik Indonesia. Penelitian yang dilakukan adalah dengan menyebarkan kuesioner, sedangkan untuk metode penelitian yang dilakukan adalah dengan menggunakan metode deskriptif. Dalam melakukan penelitian ini penulis menggunakan Analisis koefisien korelasi, Analisa regresi linier berganda dan uji F serta uji t. Dari hasil analisis penulis memperoleh hasil sebagai berikut. Dari analisis linier berganda diperoleh persamaan $\mathrm{Y}=$ $3.327+0.711 \mathrm{X} 1+0.292 \mathrm{X} 2+0.210 \mathrm{X} 3$ dimana artinya setiap peningkatan atau penurunan budaya organisasi sebesar 1 point maka kepuasan kerja akan mengalami peningkatan atau penurunan sebesar 0.711. Dari hasil uji F model didapat nilai 384.130 dimana nilai tersebut lebih besar dari F tabel yaitu 3.11 dengan demikian Ho ditolak dan Ha diterima. Pada uji t diketahui hasil bahwa $\mathrm{t}$ hitung untuk budaya organisasi (X1) adalah sebesar 9.364, hasil komunikasi (X2) adalah sebesar 3.922, dan untuk lingkungan kerja (X3) adalah 3.372.
\end{abstract}

Kata Kunci:Budaya Organisasi, Komunikasi, Lingkungan Kerja, Kepuasan Kerja

\section{Pendahuluan}

Sumber daya manusia yang berkualitas akan memberikan kekuatan untuk menjalankan strategi agar organisasi dapat mencapai tujuannya. Sumber Daya Manusia (SDM) merupakan satu-satunya sumber daya yang memiliki akal, perasaaan, keinginan, keterampilan, pengetahuan, dorongan, daya, dan karya (rasio, rasa, dan karsa). (Zainal, 2004) Karyawan merupakan sumber daya manusia yang sangat penting bagi Direktorat Jenderal Bimbingan Masyarakat Hindu Kementerian Agama Republik Indonesia (Organisasi dan Tata Kerja Kementerian Agama Republik Indonesia., 2016 ). Oleh karena itu, pengembangan sumber daya karyawan harus selalu ditingkatkan dari waktu ke waktu seiring dengan dinamika perkembangan zaman dengan pesatnya teknologi dan ilmu pengetahuan serta pergeseran nilai sosial dan budaya. Pimpinan dalam hal ini memiliki peran penting dalam meningkatkan kualitas sumber daya manusia sehingga pekerjaan yang diberikan dapat terselesaikan dengan baik dan karyawanpun dapat merasakan kepuasan kerja terhadap pekerjaannya.

Budaya organisasi dapat mempengaruhi kepuasan kerja karyawan didalam organisasi. Perkembangan dan kemajuan suatu organisasi sangat tidak bisa dikesampingkan dengan peranan format dan konsep budaya yang diterapkan diorganisasi tersebut. Budaya organisasi merupakan suatu kebiasaan yang telah berlangsung lama dan dipakai serta diterapkan dalam kehidupan aktivitas kerja para karyawan dan pimpinan organisasi. Budaya organisasi merupakan hasil dari proses pembentukan perilaku serta dipengaruhi oleh konsep-konsep dan model struktural yang diterapkan. Para karyawan juga dipengaruhi oleh sikap pimpinannya, perilaku seorang pemimpin 
menjadi contoh bagi para bawahannya, terutama kemampuan pemimpin dalam membangun serta memperlihatkan karakternya. Budaya relatif sulit untuk diubah, tetapi budaya organisasi dibuat agar lebih meningkatkan kepuasan kerja karyawan. Sehingga jika kita mempertanyakan apakah dengan budaya organisasi yang dibangun dan dikonsep dengan maksimal akan mampu memberi pengaruh pada pembentukan suatu manajemen yang baik sesuai dengan yang diinginkan oleh organisasi. Maka jawabannya adalah sangat jelas, karena jika disuatu organisasi menekankan budaya kedisiplinan dan kerja keras yang tinggi maka setiap karyawan akan terbiasa untuk bekerja keras. Dan dengan begitu juga jika pihak manajer mengakomodasi setiap prestasi karyawan dengan penghargaan, maka otomatis karyawan akan bekerja secara lebih maksimal (Andy, 2018). Dalam hal ini, budaya organisasi mencerminkan bagaimana dalam melakukan pekerjaan dalam organisasi.

Faktor lain yang dapat mempengaruhi kepuasan kerja karyawan adalah lingkungan kerja. Lingkungan kerja merupakan segala sesuatu yang ada di sekitar para pekerja dan yang mempengaruhi dirinya dalam menjalankan tugas yang dia emban atau yang menjadi tanggung jawabnya. Untuk meningkatkan produktivitasnya maka lingkungan kerja sangat mempengaruhi kinerja karena lingkungan kerja ini sendiri terdiri dari lingkungan kerja fisik dan non fisik yang melekat dengan karyawan sehingga tidak dapat dipisahkan dari usaha pengembangan kinerja karyawan. Penciptaan lingkungan kerja yang baik akan membantu memelihara kondisi fisik karyawan sehingga kesegaran fisik karyawan terjaga, tidak lekas capek, tidak lesu dalam bekerja, dan dapat bekerja lebih lama. Kondisi karyawan yang terjaga ini membuat karyawan mempunyai mental yang baik (tidak stres atau tegang, tidak tertekan, tidak bosan, merasa nyaman, senang) dalam menyelesaikan tugasnya. Lingkungan kerja yang kondusif akan mendorong efektivitas perusahaan dalam menjalankan aktivitasnya, serta akan menimbulkan semangat dan gairah kerja karyawan. Hal ini sangat bermanfaat bagi kelangsungan hidup organisasi dan akan meningkatkan produktivitas sehingga tercapainya tujuan organisasi. Karena apabila suatu lingkungan yang kurang baik seperti suara bising, suhu udara panas, kebersihan tidak terjaga dan sebagainya, dapat menurunkan kondisi fisik dan kondisi mental karyawan. Indikasi penurunan kondisi fisik dapat berupa kelelahan, kelesuan kerja, gangguan kesehatan atau sakit, akibat kerja bahkan kecelakaan kerja. Tujuan dari penelitian ini untuk mengetahui pengaruh budaya, komunikasi, lingkungan kerja organisasi terhadap kepuasan kerja karyawan pada Direktorat Jenderal Bimbingan Masyarakat Hindu Kementerian Agama Republik Indonesia

\section{Metode Penelitian}

Metode penelitian ini merupakan suatu sistem atau cara bekerja dibidang yang bersifat sistematis yng bertujuan untuk mendapatkan hasil yang memadai dalam penelitian yang bersifat ilmiah. Dalam penelitian ini penulis menggunakan beberapa metode penelitian yang merupakan salah satu cara untuk mengumpulkan data dan informasi secara objektif dan relevan sehingga memudahkan peyusunan.

Metode penelitin yang digunakan penulis adalah metode deskriptif adalah suatu metode dalam meneliti status kelompok manusia, suatu objek, suatu set kondisi, suatu sistem pemikiran, ataupun suatu kelas, peristiwa pada masa sekarang. Tujuan dari penelitian deskriptif ini adalah untuk membuat depenelitian, gambaran atau lukisan secara sistematis, faktual dan akurat mengenai faktafakta, sifat-sifat serta hubungan antar fenomena yang diselidiki.

\section{Populasi dan Sample Populasi}

(Sugiyono, 2010) didalam bukunya Metode Penelitian Pendidikan menyatakan bahwa: "Populasi adalah wilayah generalisasi yang terdiri dari atas: objek/subjek yang mempunyai kualitas dan karakteristik tertentu yang ditetapkan oleh peneliti untuk dipelajari dan kemudian ditarik kesimpulannya." 
Populasi berasal dari kata bahasa inggris population, yang berarti jumlah penduduk. Dalam metode penelitian kata populasi digunakan untuk menyebutkan serumpun atau kelompok objek yang menjadi sasaran penelitian. Oleh karena itu, populasi penelitian merupakan keseluruhan dari objek penelitian yang dapat berupa manusia, tumbuh-tumbuhan, udara, gejala, nilai, peristiwa, sikap hidup, dan sebagainya, sehingga objek-objek ini dapat menjadi sumber data penelitian.

\section{Sampel}

(Sunyoto, 2014), mengemukakan bahwa: "Bagian dari populasi yang ingin diteliti, dipandang sebagai suatu pendugaan terhadap populasi, namun bukan populasi itu sendiri."

(Sugiyono, 2010) didalam bukunya Metode Penelitian Kuantitatif Kualitatif dan R\&D terdapat beberapa ukuran sampel yaitu sebagai berikut:

1. Ukuran sampel yang layak dalam penelitian adalah antara 30 sampai dengan 500

2. Bila sampel dibagi dalam kategori (misalnya: pria-wanita, pegawai negeri-swasta dan lain-lain) maka jumlah anggota sampel setiap kategori minimal 30

3. Bila dalam penelitian akan melakukan analisis dengan korelasi atau regresi berganda maka jumlah anggota sampel minimal 10 kali dari jumlah variabel yang diteliti. Misalnya variabel penelitiannya ada 5 , maka jumlah anggota sampel $10 \times 5=50$

4. Untuk penelitian eksperimen yang sederhana, yang menggunakan kelompok eksperimen dan kelompok kontrol, maka jumlah anggota sampel masing-masing antara 10 sampai dengan 20.

\section{Hasil}

\section{Hasil Penelitian Berdasarkan Identifikasi Responden}

Hasil penelitian ini penulis mengambil beberapa orang untuk dijadikan sempel untuk merespon pertanyaan-pertanyaan yang diberikan penulis mengenai pengaruh budaya organisasi, komunikasi, dan lingkungan kerja terhadap kepuasan kerja karyawan pada Direktorat Jenderal Bimbingan Masyarakat Hindu Kementerian Agama Republik Indonesia dalam bentuk kuisioner kepada 80 responden.

Menganalisa penetapan komunikasi efektif dan penanganan komplain terhadap kepuasan kerja karyawan pada Direktorat Jenderal Bimbingan Masyarakat Hindu Kementerian Agama Republik Indonesia dengan menggunakan penelitian. Penelitian dilakukan dengan menyebarkan kuisioner kepada 80 responden dan responden memberi tanggapan terhadap beberapa pernyataan tersebut yang digunakan sebagai sampel.

\section{Hasil Responden Terhadap Data Responden}

Berikut ini adalah data mengenai profil responden yang akan dijelaskan melalui tabel dibawah ini :

Tabel 1. Perincian Responden Berdasarkan Jenis Kelamin

\begin{tabular}{|l|l|l|}
\hline Jenis Kelamin & Responden & Persentase \% \\
\hline Pria & 47 & $59 \%$ \\
\hline Wanita & 33 & $41 \%$ \\
\hline Jumlah & 80 & $100 \%$ \\
\hline
\end{tabular}

Sumber : Data Kuesioner

Berdasarkan data di atas dapat dilihat jelas bahwa terdapat jenis kelamin pria dan wanita. Dimana responden yang berjenis kelamin pria sebanyak 47 orang dengan presentase sebesar 59\% dan responden yang berjenis kelamin wanita sebanyak 33 orang dengan presentase sebesar $41 \%$. 
Tabel 2. Perincian Responden Berdasarkan Usia

\begin{tabular}{|c|l|l|}
\hline Usia & Responden & Presentase \% \\
\hline < 35 tahuan & 21 & $26 \%$ \\
\hline $\mathbf{3 5} \mathbf{- 4 5}$ tahun & 20 & $25 \%$ \\
\hline $\mathbf{4}$ 45 tahun & 39 & $49 \%$ \\
\hline Jumlah & 80 & $100 \%$ \\
\hline
\end{tabular}

Sumber : Data Kuesioner

Berdasarkan data di atas dapat dilihat jelas bahwa terdapat tingkatan usia dimana responden dengan tingkat usia $<35$ tahun sebanyak 21 orang dengan presentase sebesar $26 \%$, tingkat $35-45$ tahun sebanyak 20 orang dengan presentase sebesar 25\%, dan tingkat $>45$ tahun sebanyak 39 orang dengan persentase sebesar $49 \%$.

\section{Uji Validitas dan Reliabilitas}

\section{Uji Validitas dan Reabilitas Variabel Budaya Organisasi (X1)}

Untuk mengetahui ada tidaknya pengaruh antara variabel X1 (Budaya Organisasi), X2 (Komunikasi), dan X3 (Lingkungan Kerja) terhadap variabel Y (Kepuasan Kerja) serta mengukur kuat tidaknya pengaruh tersebut, maka digunakan reabilitas dengan menggunakan perhitungan SPSS.

Dalam penelitian ini penulis membuat 10 pernyataan yang dinyatakan untuk variabel X1 tentang budaya organisasi. Untuk mengetahui lebih lanjut, apakah semua pertnyaan tersebut reliabel, maka dapat dilakukan uji reliabilitas dengan hasil uji reliabilitas sebagai berikut:

\section{Tabel 3. Reliability Statistics}

\begin{tabular}{|c|c|}
\hline $\begin{array}{l}\text { Cronbach's } \\
\text { Alpha }\end{array}$ & N of Items \\
\hline .928 & 10 \\
\hline
\end{tabular}

Sumber : SPSS Versi 20.00

Pada tabel reliability statistic diatas, dapat dilihat bahwa nilai: Cronbach's Alpha adalah sebesar 0,928 dengan jumlah 10 pernyataan. Jika dibandingkan dengan nilai Alpha Cronbach's menurut (Uyanto, 2009) dalam bukunya "Pedoman Analisis Data dengan SPSS", maka nilai Cronbach's Alpha dari variabel pengaruh budaya organisasi lebih besar daripada nilai a=0,67757. Jadi dapat disimpulkan bahwa semua kuesioner tentang pengaruh budaya organisasi tersebut terbukti reliabel. 
Table 4. Item-Total Statistic

\begin{tabular}{|l|c|c|c|c|}
\hline & $\begin{array}{l}\text { Scale Mean } \\
\text { if } \begin{array}{l}\text { Item } \\
\text { Deleted }\end{array}\end{array}$ & $\begin{array}{l}\text { Scale } \\
\text { Variance if } \\
\text { Item Deleted }\end{array}$ & $\begin{array}{l}\text { Corrected Item- } \\
\text { Total } \\
\text { Correlation }\end{array}$ & $\begin{array}{l}\text { Cronbach's } \\
\text { Alpha if Item } \\
\text { Deleted }\end{array}$ \\
\hline Budaya Organisasi 1 & 25.7750 & 29.974 & .648 & .924 \\
Budaya Organisasi 2 & 26.6575 & 28.496 & .792 & .917 \\
Budaya Organisasi 3 & 26.0375 & 28.745 & .717 & .921 \\
Budaya Organisasi 4 & 25.8000 & 28.795 & .715 & .921 \\
Budaya Organisasi 5 & 26.2375 & 30.740 & .706 & .923 \\
Budaya Organisasi 6 & 25.8625 & 27.107 & .778 & .918 \\
Budaya Organisasi 7 & 25.8750 & 28.744 & .763 & .919 \\
Budaya Organisasi 8 & 26.2000 & 29.985 & .697 & .922 \\
Budaya Organisasi 9 & 25.8000 & 28.415 & .803 & .916 \\
Budaya Organisasi 10 & 25.9250 & 29.083 & .641 & .925 \\
\hline
\end{tabular}

Sumber : SPSS Versi 20.00

Dari data tabel diatas dapat dijelaskan bahwa :

a. Tabel Item-Total Statistics menunjukan hasil perhitungan validitas untuk 10 pernyataan.

b. Menentukan besarnya nilai $\mathrm{r}$ tabel dengan ketentuan tingkat kepercayaan (degree of freedom $=\mathrm{df}$ ) jumlah responden dikurangi 2 atau 80-2=78 dengan tingkat singnifikan 5\% maka $r$ tabel sebesar 0,2199

c. Membandingkan $\mathrm{r}$ tabel dengan setiap butir $\mathrm{r}$ hitung pernyataan dengan cara membandingkan output correlated item total correlation dengan 0,2199 ( $\mathrm{r}$ tabel)

d. Jika dibandingkan dengan $\mathrm{r}$ tabel pada kolom corrected item total correlation.

e. Nilai $r$ hitung semua pernyataan tentang budaya organisasi lebih besar $r$ tabel artinya semua pernyataan sudah valid.

\section{Uji Validitas dan Reliability Komunikasi (X2)}

Dalam penelitian ini penulis membuat 10 pernyataan yang dinyatakan untuk variabel X2 tentang komunikasi. Untuk mengetahui lebih lanjut, apakah semua pernyataan tersebut reliabel, maka dapat dilakukan uji reliabilitas dengan hasil uji reliabilitas sebagai berikut :

Dari tabel case processing summary diatas dapat dilihat bahwa responden yang diteliti pada hasil uji kuesioner mengenai variabel komunikasi berjumlah 80 orang dan semua data tidak ada yang dikeluarkan (exclude) dari analisis.

Tabel 5. Reliability Statistics

\begin{tabular}{|c|c|}
\hline $\begin{array}{c}\text { Cronbach's } \\
\text { Alpha }\end{array}$ & $\begin{array}{c}\mathrm{N} \\
\text { Items }\end{array}$ \\
\hline .867 & 10 \\
\hline
\end{tabular}

Sumber : SPSS Versi 20.00

Pada tabel reliability statistic diatas, dapat dilihat bahwa nilai : Cronbach's Alpha adalah sebesar 0,867 dengan jumlah 10 pernyataan. Jika dibandingkan dengan nilai Alpha Cronbach's menurut (Uyanto, 2009) dalam bukunya "Pedoman Analisis Data dengan SPSS", maka nilai Cronbach's Alpha dari variabel pengaruh komunikasi lebih besar daripada nilai a $=0.67757$. Jadi dapat disimpulkan bahwa semua kuesioner tentang pengaruh komunikasi tersebut terbukti reliabel. 
Table 6. Item-Total Statistic

\begin{tabular}{|l|l|c|c|c|}
\hline & $\begin{array}{l}\text { Scale Mean } \\
\text { if Item } \\
\text { Deleted }\end{array}$ & $\begin{array}{l}\text { Scale } \\
\text { Variance if } \\
\text { Item Deleted }\end{array}$ & $\begin{array}{l}\text { Corrected Item- } \\
\text { Total } \\
\text { Correlation }\end{array}$ & $\begin{array}{l}\text { Cronbach's } \\
\text { Alpha if Item } \\
\text { Deleted }\end{array}$ \\
\hline Komunikasi 1 & 25.1375 & 25.943 & .660 & .848 \\
Komunikasi 2 & 25.3375 & 27.644 & .530 & .859 \\
Komunikasi 3 & 25.4625 & 25.745 & .616 & .852 \\
Komunikasi 4 & 25.5500 & 26.504 & .597 & .853 \\
Komunikasi 5 & 25.3625 & 25.145 & .763 & .839 \\
Komunikasi 6 & 25.5875 & 27.916 & .615 & .854 \\
Komunikasi 7 & 25.3875 & 25.607 & .694 & .845 \\
Komunikasi 8 & 25.5500 & 27.441 & .487 & .863 \\
Komunikasi 9 & 25.4500 & 27.643 & .523 & .859 \\
Komunikasi 10 & 25.7625 & 30.133 & .326 & .871 \\
\hline
\end{tabular}

Sumber : SPSS Versi 20.00

Dari data tabel diatas dapat dijelaskan bahwa :

a. Tabel Item-Total Statistics menunjukan hasil perhitungan validitas untuk 10 pernyataan.

b. Menentukan besarnya nilai $\mathrm{r}$ tabel dengan ketentuan tingkat keprcayaan (degree of freedom $=\mathrm{df}$ ) jumlah responden dikurangi 2 atau 80-2=78 dengan tingkat singnifikan 5\% maka $r$ tabel sebesar 0,2199

c. Membandingkan $\mathrm{r}$ tabel dengan setiap butir $\mathrm{r}$ hitung pernyataan dengan cara membandingkan output correlated item total correlation dengan 0,2199 ( $\mathrm{r}$ tabel)

d. Jika dibandingkan dengan $\mathrm{r}$ tabel pada kolom corrected item total correlation.

e. Nilai $r$ hitung semua pernyataan tentang komunikasi lebih besar $r$ tabel artinya semua pernyataan sudah valid.

\section{Uji Validitas dan Reliability Lingkungan Kerja (X3)}

Dalam penelitian ini penulis membuat 10 pernyataan yang dinyatakan untuk variabel X3 tentang lingkungan kerja. Untuk mengetahui lebih lanjut, apakah semua pernyataan tersebut reliabel, maka dapat dilakukan uji relibilitas dengan hasil uji reliabilitas sebagai berikut :

Dari tabel case processing summary diatas dapat dilihat bahwa responden yang diteliti pada hasil uji kuesioner mengenai variabel kinerja karyawan berjumlah 80 orang dan semua data tidak ada yang dikeluarkan (exclude) dari analisis.

\section{Tabel 7. Reliability Statistics}

\begin{tabular}{|c|c|}
\hline $\begin{array}{c}\text { Cronbach's } \\
\text { Alpha }\end{array}$ & $\begin{array}{c}\mathrm{N} \\
\text { Items }\end{array}$ \\
\hline .916 & 10 \\
\hline
\end{tabular}

Sumber : SPSS Versi 20.00

Dari tabel reliability statistic diatas, dapat dilihat bahwa nilai Cronbach 's Alpha adalah sebesar 0,916 dengan jumlah 10 pernyataan. Jika dibandingkan dengan nilai Alpha Cronbach's menurut (Uyanto, 2009) dalam bukunya "Pedoman Analisis Data dengan SPSS", maka nilai Cronbach's Alpha dari variabel pengaruh lingkungan kerja lebih besar daripada nilai a $=0,67757$. Jadi dapat disimpulkan bahwa semua kuesioner tentang pengaruh lingkungan kerja tersebut terbukti reliabel. 
Tabel 8. Item-Total Statistics

\begin{tabular}{|l|c|c|c|c|}
\hline & $\begin{array}{c}\text { Scale Mean } \\
\text { if Item Deleted }\end{array}$ & $\begin{array}{c}\text { Scale } \\
\text { Variance if Item } \\
\text { Deleted }\end{array}$ & $\begin{array}{c}\text { Corrected } \\
\text { Item-Total } \\
\text { Correlation }\end{array}$ & $\begin{array}{c}\text { Cronbach's } \\
\text { Alpha if Item } \\
\text { Deleted }\end{array}$ \\
\hline Lingkungan Kerja 1 & 27.5000 & 33.949 & .705 & .908 \\
Lingkungan Kerja 2 & 27.8000 & 32.694 & .909 & .892 \\
Lingkungan Kerja 3 & 27.8875 & 33.899 & .827 & .898 \\
Lingkungan Kerja 4 & 28.0750 & 35.488 & .787 & .901 \\
Lingkungan Kerja 5 & 28.3500 & 37.522 & .767 & .904 \\
Lingkungan Kerja 6 & 28.1000 & 37.458 & .598 & .912 \\
Lingkungan Kerja 7 & 27.8750 & 38.415 & .638 & .910 \\
Lingkungan Kerja 8 & 28.1125 & 39.038 & .559 & .914 \\
Lingkungan Kerja 9 & 27.9500 & 38.985 & .538 & .915 \\
Lingkungan Kerja 10 & 28.1375 & 37.715 & .592 & .912 \\
\hline
\end{tabular}

Sumber : SPSS Versi 20.00

Dari data tabel diatas dapat dijelaskan bahwa :

a. Tabel Item-Total Statistics menunjukan hasil perhitungan validitas untuk 10 pernyataan.

b. Menentukan besarnya nilai $\mathrm{r}$ tabel dengan ketentuan tingkat keprcayaan (degree of freedom $=\mathrm{df}$ ) jumlah responden dikurangi 2 atau $80-2=78$ dengan tingkat singnifikan $5 \%$ maka $r$ tabel sebesar 0,2199

c. Membandingkan $\mathrm{r}$ tabel dengan setiap butir $\mathrm{r}$ hitung pernyataan dengan cara membandingkan output correlated item total correlation dengan 0,2199 ( $\mathrm{r}$ tabel)

d. Jika dibandingkan dengan $r$ tabel pada kolom corrected item total correlation.

e. Nilai $r$ hitung semua pernyataan tentang lingkungan kerja lebih besar $r$ tabel artinya semua pernyataan sudah valid.

\section{Uji Validitas dan Reliability Kepuasan Kerja (Y)}

Dalam penelitian ini penulis membuat 10 pernyataan yang dinyatakan untuk variabel $Y$ tentang kepuasan kerja. Untuk mengetahui lebih lanjut, apakah semua pernyataan tersebut reliabel, maka dapat dilakukan uji relibilitas dengan hasil uji reliabilitas sebagai berikut:

Tabel 9. Reliability Statistics

\begin{tabular}{|c|c|}
\hline $\begin{array}{c}\text { Cronbach's } \\
\text { Alpha }\end{array}$ & N of Items \\
\hline .849 & 10 \\
\hline
\end{tabular}

Sumber : SPSS Versi 20.00

Dari tabel reliability statistic diatas, dapat dilihat bahwa nilai Cronbach's Alpha adalah sebesar 0,849 dengan jumlah 10 pernyataan. Jika dibandingkan dengan nilai Alpha Cronbach's menurut (Uyanto, 2009) dalam bukunya "Pedoman Analisis Data dengan SPSS", maka nilai Cronbach's Alpha dari variabel pengaruh kepuasan kerja lebih besar daripada nilai a = 0,67757. Jadi dapat disimpulkan bahwa semua kuesioner tentang pengaruh kepuasan kerja tersebut terbukti reliabel. 
Tabel 10. Item-Total Statistics

\begin{tabular}{|l|c|c|c|c|}
\hline & $\begin{array}{c}\text { Scale Mean } \\
\text { if Item Deleted }\end{array}$ & $\begin{array}{c}\text { Scale } \\
\text { Variance if Item } \\
\text { Deleted }\end{array}$ & $\begin{array}{c}\text { Corrected } \\
\text { Item-Total } \\
\text { Correlation }\end{array}$ & $\begin{array}{c}\text { Cronbach's } \\
\text { Alpha if Item } \\
\text { Deleted }\end{array}$ \\
\hline Kepuasan Kerja 1 & 34.6000 & 37.509 & .808 & .808 \\
Kepuasan Kerja 2 & 35.0250 & 37.518 & .823 & .807 \\
Kepuasan Kerja 3 & 34.5250 & 42.759 & .481 & .841 \\
Kepuasan Kerja 4 & 35.3125 & 39.787 & .685 & .822 \\
Kepuasan Kerja 5 & 34.8000 & 38.997 & .620 & .828 \\
Kepuasan Kerja 6 & 34.5375 & 46.176 & .226 & .862 \\
Kepuasan Kerja 7 & 34.6250 & 43.934 & .511 & .838 \\
Kepuasan Kerja 8 & 34.5875 & 44.954 & .389 & .847 \\
Kepuasan Kerja 9 & 34.6625 & 43.745 & .444 & .843 \\
Kepuasan Kerja 10 & 34.6125 & 41.785 & .503 & .839 \\
\hline
\end{tabular}

Sumber : SPSS Versi 20.00

Dari data tabel diatas dapat dijelaskan bahwa :

a. Tabel Item-Total Statistics menunjukan hasil perhitungan validitas untuk 10 pernyataan.

b. Menentukan besarnya nilai $r$ tabel dengan ketentuan tingkat keprcayaan (degree offreedom $=\mathrm{df})$ jumlah responden dikurangi 2 atau $80-2=78$ dengan tingkat singnifikan 5\% maka $r$ tabel sebesar 0,2199

c. Membandingkan $\mathrm{r}$ tabel dengan setiap butir $\mathrm{r}$ hitung pernyataan dengan cara membandingkan output correlated item total correlation dengan 0,2199 ( $\mathrm{r}$ tabel)

d. Jika dibandingkan dengan $\mathrm{r}$ tabel pada kolom corrected item total correlation.

e. Nilai $r$ hitung semua pernyataan tentang kepuasan kerja lebih besar $r$ tabel artinya semua pernyataan sudah valid.

\section{Analisis Pengaruh Budaya Organisasi, Komunikasi, dan Lingkungan Kerja terhadap Kepuasan Kerja Karyawan}

Untuk mengetahui ada tidaknya pengaruh antara variabel X1 (Budaya Organisasi), variabel X2 (Komunikasi), dan variabel X3 (Lingkungan Kerja) dengan variabel Y (Kepuasan Kerja Karyawan) serta mengukur kuat tidaknya pengaruh tersebut, maka digunakan analisa regresi linear berganda dengan menggunakan perhitungan SPSS (Statistical Package For Service Softition), berikut ini hasil analisis regresi linear berganda adalah sebagai berikut:

Tabel 11. Descriptive Statistics

\begin{tabular}{|l|c|c|c|}
\hline & Mean & $\begin{array}{c}\text { Std. } \\
\text { Deviation }\end{array}$ & $\mathrm{N}$ \\
\hline Kepuasan Kerja Karyawan & 38.59 & 7.117 & 80 \\
Budaya Organisasi & 28.80 & 5.961 & 80 \\
Komunikasi & 28.29 & 5.728 & 80 \\
Lingkungan Kerja & 31.09 & 6.683 & 80 \\
\hline
\end{tabular}

Sumber : Sumber : SPSS Versi 20.00

Dari tabel diatas dapat dilihat bahwa :

a. Mean (Rata-rata) dari variabel Y (Kepuasan Kerja Karyawan) dengan jumlah responden 80 orang dalah 38.59 dengan standar deviasi sebesar 7.117 
b. Mean (Rata-rata) dari variabel X1 (Budaya Organisasi) dengan jumlah responden 80 orang adalah 28.80 dengan standar deviasi sebesar 5.961

c. Mean (Rata-rata) dari variabel X2 (Komunikasi) dengan jumlah responden 80 orang adalah 28.29 dengan standar deviasi sebesar 5.728

d. Mean (Rata-rata) dari variabel X3 (Lingkungan Kerja) dengan jumlah responden 80 orang adalah 31.09 dengan standar deviasi sebesar 6.683

Tabel 12. Correlations

\begin{tabular}{|ll|c|c|c|c|}
\hline & & $\begin{array}{l}\text { Kepuasan } \\
\text { Kerja } \\
\text { Karyawan }\end{array}$ & $\begin{array}{l}\text { Budaya } \\
\text { Organisasi }\end{array}$ & $\begin{array}{l}\text { Komunik } \\
\text { asi }\end{array}$ & $\begin{array}{l}\text { Lingkungan } \\
\text { Kerja }\end{array}$ \\
\hline Pearson & Kepuasan Kerja Karyawan & 1.000 & .912 & .809 & .788 \\
Correlation & Budaya Organisasi & .912 & 1.000 & .739 & .724 \\
& Komunikasi & .809 & .739 & 1.000 & .680 \\
& Lingkungan Kerja & .788 & .724 & .680 & 1.000 \\
\hline Sig. & $(1-$ Kepuasan Kerja Karyawan &. & .000 & .000 & .000 \\
tailed) & Budaya Organisasi & .000 &. & .000 & .000 \\
& Komunikasi & .000 & .000 &. & .000 \\
& Lingkungan Kerja & .000 & .000 & .000 &. \\
\hline $\mathrm{N}$ & Kepuasan Kerja Karyawan & 80 & 80 & 80 & 80 \\
& Budaya Organisasi & 80 & 80 & 80 & 80 \\
& Komunikasi & 80 & 80 & 80 & 80 \\
& Lingkungan Kerja & 80 & 80 & 80 & 80 \\
\hline
\end{tabular}

Sumber : SPSS Versi 20.00

Dari tabel diatas dapat dilihat bahwa :

a. Besar hubungan pengaruh budaya organisasi ditunjukan dengan nilai koefisien korelasi sebesar 0.912 mendekati 1, dimana korelasi memiliki pengaruh yang positif dan kuat. Besar pengaruh komunikasi ditunjukan dengan nilai koefisien korelasi sebesar 0.809 mendekati 1, dimana korelasi memiliki pengaruh yang positif dan kuat. Besar pengaruh lingkungan kerja ditunjukan dengan nilai koefisien korelasi sebesar 0.788 mendekati 1, dimana korelasi memiliki pengaruh yang positif dan kuat. Jadi pengaruh budaya organisasi, komunikasi, dan lingkungan kerja adalah kuat dan mempunyai pengaruh yang positif. Hal ini berarti dapat dikatakan bahwa budaya organisasi, komunikasi, dan lingkungan kerja memberi pengaruh terhadap kinerja karyawan. Arah hubungan pengaruh yang positif menunjukan semakin baik budaya organisasi, terjalinnya komunikasi, dan lingkungan kerja akan membuat kepuasan kerja karyawan cenderung meningkat. Demikian pula sebaliknya, semakin buruk budaya organisasi, komunikasi, dan lingkungan kerja dapat menurunkan tingkat kepuasan kerja karyawan.

b. Tabel Correlation menunjukan bahwa : Pengaruh budaya organisasi, komunikasi, dan lingkungan kerja dapat dilihat dari angka probalitas sebesar $0,000<0,05$ menyebutkan bahwa jika angka probalitas < dari 0,05 maka terdapat pengaruh yang signifikan antar ketiga variabel tersebut. Nilai signifikan sebesar 0,000 menunjukan hasil korelasi ketiga variabel adalah signifikan artinya menolak Ho dan menerima Ha. 
Tabel 13. Variables Entered/Removed ${ }^{a}$

\begin{tabular}{|c|c|c|c|}
\hline Model & $\begin{array}{l}\text { Variables } \\
\text { Entered }\end{array}$ & $\begin{array}{l}\text { Variables } \\
\text { Removed }\end{array}$ & Method \\
\hline 1 & $\begin{array}{l}\text { Budaya } \\
\text { Organisasi }\end{array}$ & & $\begin{array}{l}\text { Stepwise (Criteria: } \\
\text { Probability-of-F-to-enter } \\
<=.050, \text { Probability-of- } \\
\text { F-to-remove }>=.100) .\end{array}$ \\
\hline 2 & Komunikasi & - & $\begin{array}{l}\text { Stepwise (Criteria: } \\
\text { Probability-of-F-to-enter } \\
<=.050, \text { Probability-of- } \\
\text { F-to-remove }>=.100) .\end{array}$ \\
\hline 3 & $\begin{array}{l}\text { Lingkungan } \\
\text { Kerja }\end{array}$ & - & $\begin{array}{l}\text { Stepwise (Criteria: } \\
\text { Probability-of-F-to-enter } \\
<=.050, \text { Probability-of- } \\
\text { F-to-remove }>=.100) .\end{array}$ \\
\hline
\end{tabular}

a. Dependent Variable: Kepuasan Kerja

Sumber : SPSS Versi 20.00

Dari tabel diatas dapat dilihat bahwa: menurut metode stepwise dimulai dengan memasukkan semua variabel kemudian di analisis dan variabel yang tidak layak masuk dalam regresi dikeluarkan satu persatu. Dengan demikian variabel budaya organisasi (X1), Komunikasi (X2), dan Lingkungan Kerja (X3) merupakan variabel masukan (Variabel Entered), karena probabilitas dari budaya organisasi, komunikasi, dan lingkungan kerja memenuhi kriteria probabilitas. Dimana probabilitas dari budaya organisasi, komunikasi, dan lingkungan kerja dibawah alpha 0.05.

Pengujian signifikasi korelasi ini dilakukan dengan pengujian satu sisi, dimana dasar pengambilan keputusannya adalah berdasarkan probabilitas. Jika probabilitas $(\mathrm{P}>\mathrm{Alpha}=0.05)$ maka Ho ditolak dan Ha diterima.

Tabel 14. Model Summary

\begin{tabular}{|c|c|c|c|c|c|c|c|c|c|}
\hline \multirow[b]{2}{*}{$\begin{array}{l}\text { Mod } \\
\text { el }\end{array}$} & \multirow[b]{2}{*}{$\mathrm{R}$} & \multirow[b]{2}{*}{$\begin{array}{l}\mathrm{R} \\
\text { Square }\end{array}$} & \multirow[b]{2}{*}{$\begin{array}{l}\text { Adjust } \\
\text { ed R R } \\
\text { Square }\end{array}$} & \multirow{2}{*}{$\begin{array}{l}\text { Std. } \\
\text { Error of } \\
\text { the } \\
\text { Estimate }\end{array}$} & \multicolumn{5}{|c|}{ Change Statistics } \\
\hline & & & & & $\begin{array}{l}\text { R Square } \\
\text { Change }\end{array}$ & \begin{tabular}{|l} 
F \\
Change
\end{tabular} & df1 & df2 & $\begin{array}{l}\text { Sig. F } \\
\text { Change }\end{array}$ \\
\hline 1 & $.912^{\mathrm{a}}$ & .831 & .829 & 2.943 & .831 & 384.130 & 1 & 78 & .000 \\
\hline 2 & $.934^{b}$ & .872 & .868 & 2.583 & .040 & 24.238 & 1 & 77 & .000 \\
\hline 3 & $.943^{\mathrm{c}}$ & .888 & .884 & 2.425 & .017 & 11.373 & 1 & 76 & .001 \\
\hline
\end{tabular}

a. Predictors: (Constant), Budaya Organisasi

b. Predictors: (Constant), Budaya Organisasi, Komunikasi

c. Predictors: (Constant), Budaya Organisasi, Komunikasi, Lingkungan Kerja

d. Dependent Variable: Kepuasan Kerja

Sumber : SPSS Versi 20.00

Dari tabel diatas dapat dilihat bahwa:

a. Kolom R untuk model 1 menunjukkan bahwa angka koefisien korelasi yaitu sebesar 0.912. Hal ini berarti pengaruh antara budaya organisasi terhadap kepuasan kerja karyawan kuat.

b. Kolom $\mathrm{R}$ untuk model 1 menunjukan angka $R$ square adalah 0.831 (adalah pengkuadratan dari koefisien korelasi atau 0.912 x $0.912=0.831) . R$ Square disebut juga koefisien 
determinasi. Hal ini berarti besarnya pengaruh budaya organisasi terhadap kepuasan kerja karyawan adalah $(83,1 \%)$.

c. $R$ Square berkisar pada 0 sampai 1 , Semakin kecil angka $\mathrm{R}$ Square menunjukan semakin lemah hubungan antar variabel dan sebaliknya.

d. Kolom Adjusted R Square untuk model 1 adalah sebagai berikut sebesar 0.829 .

e. Kolom Standar Error Of The Estimate untuk model 1 adalah 2.943

f. Berdasarkan Descriptive Statistics diatas bahw nilai standar deviasi kepuasan kerja karyawan adalah 7.117 yang jauh lebih besar dari Standar Error Of The Estimate yang hanya sebesar 2.943

g. Kolom R untuk model 2 menunjukan bahwa angka koefisien korelasi yaitu sebesar 0.934 . hal ini berarti pengaruh antara budaya organisasi dan komunikasi terhadap kepuasan kerja adalah kuat.

h. Kolom R Square untuk model 2 menunjukan angka $R$ Square adalah 0.872 (adalah pengkuadratan dari koefisien korelasi atau 0.934 x $0.934=0.872$ ). $R$ Square disebut juga koefisien determinasi. Hal ini berarti besarnya pengaruh budaya organisasi dan komunikasi terhadap kepuasan kerja adalah sebesar $(87,2 \%)$. $R$ Square berkisar pada 0 sampai 1, semakin kecil angka $R$ Square menunjukan semakin kuat hubungan antara variabel dan sebaliknya.

i. Kolom Adjusted $R$ Square untuk model 2 adalah sebesar 0.868

j. Kolom Standar Error Of Estimate untuk model 2 adalah sebesar 2.583

Berdasarkan Descriptive Statistics diatas bahwa nilai standar deviasi kepuasan kerja karyawan adalah 7.117 yang jauh lebih besar dari Standar Error Of The Estimate yang hanya sebesar 2.583

a. Kolom R untuk model 3 menunjukan bahwa angka koefisien korelasi yaitu sebesar 0.943. hal ini berarti pengaruh antara budaya organisasi, komunikasi, dan lingkungan kerja terhadap kepuasan kerja adalah kuat.

b. Kolom R Square untuk model 3 menunjukan angka $R$ Square adalah 0.888 (adalah pengkuadratan dari koefisien korelasi atau $0.943 \times 0.943=0.888)$. $R$ Square disebut juga koefisien determinasi. Hal ini berarti besarnya pengaruh budaya organisasi, komunikasi, dan lingkungan kerja terhadap kepuasan kerja adalah sebesar $(88,8 \%)$. $R$ Square berkisar pada 0 sampai 1 , semakin kecil angka $R$ Square menunjukan semakin kuat hubungan antara variabel dan sebaliknya.

c. Kolom Adjusted R Square untuk model 3 adalah sebesar 0.884 .

d. Kolom Standar Error Of Estimate untuk model 3 adalah sebesar 2.425.

Berdasarkan Descriptive Statistics diatas bahw nilai standar deviasi kepuasan kerja karyawan adalah 7.117 yang jauh lebih besar dari Standar Error of the Estimate yang hanya sebesar 2.425 . 
Tabel 15. ANOVA ${ }^{\mathrm{a}}$

\begin{tabular}{|c|l|c|c|c|c|c|}
\hline \multicolumn{2}{|c|}{ Model } & $\begin{array}{c}\text { Sum of } \\
\text { Squares }\end{array}$ & df & $\begin{array}{c}\text { Mean } \\
\text { Square }\end{array}$ & F & Sig. \\
\hline \multirow{2}{*}{1} & Regression & 3326.019 & 1 & 3326.019 & 384.130 & $.000^{\mathrm{b}}$ \\
\cline { 2 - 7 } & Residual & 675.369 & 78 & 8.659 & & \\
\cline { 2 - 7 } & Total & 4001.388 & 79 & & & \\
\hline \multirow{2}{*}{2} & Regression & 3487.715 & 2 & 1743.857 & 261.406 & $.000^{\mathrm{c}}$ \\
\cline { 2 - 7 } & Residual & 513.673 & 77 & 6.671 & & \\
\cline { 2 - 7 } & Total & 4001.388 & 79 & & & \\
\hline \multirow{2}{*}{3} & Regression & 3554.577 & 3 & 1184.859 & 201.538 & $.000^{\mathrm{d}}$ \\
\cline { 2 - 7 } & Residual & 446.811 & 76 & 5.879 & & \\
\cline { 2 - 7 } & Total & 4001.388 & 79 & & & \\
\hline
\end{tabular}

a. Dependent Variable: Kepuasan Kerja

b. Predictors: (Constant), Budaya Organisasi

c. Predictors: (Constant), Budaya Organisasi, Komunikasi

d. Predictors: (Constant), Budaya Organisasi, Komunikasi, Lingkunga Kerja

Sumber : SPSS Versi 20.00

Dari tabel diatas dapat dilihat bahwa:

a. Dari uji ANOVA didapat $F$ hitung untuk model 1 adalah 384.130 dengan tingkat signifikan 0.000 dimana angka $0.000<0.05$ dan juga $F$ hitung $>\mathrm{F}$ tabel atau $384.130>3.11$, dengan demikian Ho ditolak dan Ha diterima artinya terdapat pengaruh linier antara variabel budaya organisasi dengan kepuasan kerja karyawan, maka model regresi tersebut sudah layak dan tepat untuk memprediksi kepuasan kerja karyawan.

b. Dari uji ANOVA didapat $F$ hitung untuk model 2 adalah 261.406 dengan tingkat signifikan 0.000 dimana angka $0.000<0.05$ dan juga $F$ hitung $>F$ tabel atau $261.406>3.11$, dengan demikian Ho ditolak dan Ha diterima artinya terdapat pengaruh linier antara variabel budaya organisasi dan komunikasi dengan kepuasan kerja karyawan, maka model regresi tersebut sudah layak dan tepat untuk memprediksi kepuasan kerja karyawan.

c. Dari uji ANOVA didapat $F$ hitung untuk model 3 adalah 201.538 dengan tingkat signifikan 0.000 dimana angka $0.000<0.05$ dan juga $F$ hitung $>\mathrm{F}$ tabel atau $201.538>3.11$, dengan demikian Ho ditolak dan Ha diterima artinya terdapat pengaruh linier antara variabel budaya organisasi, komunikasi, dan lingkungan kerja dengan kepuasan kerja karyawan, maka model regresi tersebut sudah layak dan tepat untuk memprediksi kepuasan kerja karyawan. 
Tabel 16. Coefficients ${ }^{\mathrm{a}}$

\begin{tabular}{|c|c|c|c|c|c|c|}
\hline \multirow{2}{*}{\multicolumn{2}{|c|}{ Model }} & \multicolumn{2}{|c|}{$\begin{array}{l}\text { Unstandardized } \\
\text { Coefficients }\end{array}$} & \multirow{2}{*}{$\begin{array}{c}\text { Standardized } \\
\text { Coefficients } \\
\text { Beta } \\
\end{array}$} & \multirow[b]{2}{*}{$\mathrm{T}$} & \multirow{3}{*}{$\begin{array}{l}\text { Sig. } \\
.000\end{array}$} \\
\hline & & B & \begin{tabular}{|l} 
Std. \\
Error
\end{tabular} & & & \\
\hline \multirow[t]{2}{*}{1} & (Constant) & 7.237 & 1.633 & & 4.431 & \\
\hline & Budaya Organisasi & 1.089 & .056 & .912 & 19.599 & .000 \\
\hline \multirow[t]{3}{*}{2} & (Constant) & 4.331 & 1.550 & & 2.794 & .007 \\
\hline & Budaya Organisasi & .826 & .072 & .691 & 11.414 & .000 \\
\hline & Komunikasi & .371 & .075 & .298 & 4.923 & .000 \\
\hline \multirow[t]{4}{*}{3} & (Constant) & 3.327 & 1.485 & & 2.239 & .028 \\
\hline & Budaya Organisasi & .711 & .076 & .595 & 9.364 & .000 \\
\hline & Komunikasi & .292 & .074 & .235 & 3.922 & .000 \\
\hline & Lingkungan Kerja & .210 & .062 & .197 & 3.372 & .001 \\
\hline
\end{tabular}

a. Dependent Variable: Kepuasan Kerja

Sumber : SPSS Versi 20.00

Dari data diatas dapat dilihat bahwa :

a. Untuk penyusunan persamaan regresi dari data diatas, dapat menggunakan nilai-nilai dari kolom B yaitu kolom Unstandardized Coefficients. Dari kolom B ini dapat nilai konstan sebesar 3.327 sedangkan untuk nilai koefisien budaya organisasi sebesar 0.711 , nilai koefisien komunikasi sebesar 0.292, dan nilai koefisien lingkungan kerja sebesar 0.210.

b. Dari nilai-nilai koefisien diatas didapat persamaan regresi sebagai berikut :

$$
\begin{aligned}
& \mathrm{Y}=\mathrm{a}+\mathrm{b} 1 \mathrm{X} 1+\mathrm{b} 2 \mathrm{X} 2+\mathrm{b} 3 \mathrm{X} 3 \\
& \mathrm{a}=\text { Konstan } \\
& \mathrm{Y}=\text { Kepuasan Kerja } \\
& \mathrm{X} 1=\text { Budaya Organisasi } \\
& \mathrm{X} 2=\text { Komunikasi } \\
& \mathrm{X} 3=\text { Lingkungan Kerja } \\
& \mathrm{b} 1, \mathrm{~b} 2, \mathrm{~b} 3=\text { Koefisien Regresi } \\
& \text { Maka diperoleh persamaan, } \\
& \mathrm{Y}=3.327+0.711 \mathrm{X} 1+0.292 \mathrm{X} 2+0.210 \mathrm{X} 3 \\
& \mathrm{Y}=\text { Kepuasan Kerja } \\
& \mathrm{X} 1=\text { Budaya Organisasi } \\
& \mathrm{X} 2=\text { Komunikasi } \\
& \mathrm{X} 3=\text { Lingkungan Kerja }
\end{aligned}
$$

c. Pada saat variabel X1 (Budaya Organisasi) terjadi peningkatan atau penurunan sebesar 1 poin maka variabel $\mathrm{Y}$ (Kepuasan Kerja) akan mengalami peningkatan atau penurunan sebesar 0.711 .

d. Pada saat variabel X2 (Komunikasi) terjadi peningkatan atau penurunan sebesar 1 poin maka Y (Kepuasan Kerja) akan mengalami peningkatan atau penurunan sebesar 0.292.

e. Pada saat variabel X3 (Lingkungan Kerja) terjadi peningkatan atau penurunan sebesar 1 poin maka variabel $\mathrm{Y}$ (Kepuasan Kerja) akan mengalami peningkatan atau penurunan sebesar 0.210 .

f. Untuk regresi berganda, angka korelasi budaya organisasi sebesar 0.595, angka korelasi komunikasi sebesar 0.235, dan angka korelasi lingkungan kerja sebesar 0.197 adalah hasil yang didapat pada kolom Standardized Coefficients (Beta). 
g. Pada kolom $t$ digunakan pengujian $t$ untuk menguji kebenaran dari hipotesis yang ada, dilakukan dengan cara mebandingkan nilai t hitung yang telah diperoleh dengan nilai tabel. Kriteria pengujian :

Jika T hitung $>$ T tabel maka Ho ditolak dan Ha diterima.

Jika T hitung < T tabel maka Ho diterima dan Ha ditolak.

h. Pada kolom t diketahui bahwa T hitung untuk Budaya Organisasi (X1) adalah sebesar 9.364 dengan menggunakan tabel distribusi normal t dan menggunakan tingkat keyakinan pengujian $(1-\alpha)$ sebesar 95\% dan tingkat kesalahan $(\alpha) n-2=80-2=78$, maka diperoleh nilai distribusi tabel $\mathrm{t}$ adalah 1.990. Oleh karena t hitung untuk budaya organisasi lebih besar dari nilai t tabel atau $9.364>1.990$, maka Ho ditolak dan Ha diterima. Untuk kolom t hitung untuk komunikasi (X2) adalah 3.922 dengan menggunakan tabel distribusi normal $\mathrm{t}$ dan menggunakan tingkat keyakinan pengujian (1- $\alpha$ ) sebesar $95 \%$ dan tingkat kesalahan $(\alpha) n-2=80-2=78$, maka diperoleh nilai distribusi tabel $\mathrm{t}$ adalah 1.990. oleh karena $\mathrm{t}$ hitung untuk komunikasi lebih besar dari nilai t tabel atau $(3.922<1.990)$, maka Ho ditolak dan Ha diterima. Sedangkan untuk kolom t hitung untuk lingkungan kerja (X3) adalah 3.372 dengan menggunakan tabel distribusi normal t dan menggunakan tingkat keyakinan pengujian (1- $\alpha$ ) sebesar 95\% dan tingkat kesalahan $(\alpha) n-2=80-2=78$, maka diperoleh nilai distribusi tabel $t$ adalah 1.990. oleh karena t hitung untuk lingkungan kerja lebih besar dari nilai t tabel atau $(3.372>1.990)$, maka Ho ditolak dan Ha diterima.

i. Pada kolom sig digunakan untuk pengujian probalitas. Kriteria pengujian:

Jika probalitas $>0.05$ maka Ho ditolak dan Ha diterima

Jika probalitas $<0.05$ maka Ho diterima dan Ha ditolak

j. Terlihat pada kolom sig diketahui nilai probabilitas budaya organisasi sebesar 0.000 , nilai probabilitas komunikasi sebesar 0.000 , nilai probabilitas lingkungan kerja sebesar 0.001 dengan demikian probabilitas dibawah 0.05 dengan demikian Ho ditolak dan Ha diterima atau koefisien regresi signifikan atau budaya organisasi, komunikasi, dan lingkungan kerja berpengaruh terhadap kepuasan kerja karyawan.

\section{Kesimpulan}

Berdasarkan hasil analisis penelitian dan pembahasan yang telah dilakukan pada Direktorat Jenderal Bimbingan Masyarakat Hindu Kementerian Agama Republik Indonesia, maka penulis menarik kesimpulan sebagai berikut :

1. Budaya Organisasi

Berdasarkan hasil jawaban kuesioner dengan jumlah sampel sebanyak 80 responden dari kuesioner yang disebarkan oleh penulis menyatakan bahwa sebagaian besar responden cukup setuju dengan pernyataan sebesar $80 \%$ yang diajukan penulis mengenai budaya organisasi.

2. Komunikasi

Berdasarkan hasil kuesioner dengan jumlah sampel sebanyak 80 responden dari kuesioner yang disebarkan oleh penulis menyatakan bahwa sebagian besar responden tidak setuju dengan pernyataan sebesar $80 \%$ yang diajukan penulis mengenai komunikasi.

3. Lingkungan Kerja

Berdasarkan hasil jawaban kuesioner dengan jumlah sampel sebanyak 80 responden dari kuesioner yaang disebarkan oleh penulis menyatakan bahwa sebagian besar responden cukup setuju dengan pernyataan sebesar $80 \%$ yang diajukan penulis mengenai lingkungan kerja.

4. Kepuasan Kerja

Berdasarkan hasil jawaban kuesioner dengan jumlah sampel sebanyak 80 responden dari kuesioner yang disebarkan oleh penulis menyatakan bahwa sebagian besar responden sangat setuju dengan pernyataan sebesar 79,6\% yang diajukan penulis mengenai kepuasan kerja. 


\section{Daftar Pustaka}

Andy, A. (2018). Analisis Pengaruh Kedisiplinan, Prestasi Dan Semangat Kerja Terhadap Pemberian Bonus Karyawan Pada PT. Reka Sukses Adipratam. Primanomics, 18-33.

Organisasi dan Tata Kerja Kementerian Agama Republik Indonesia., Peraturan Menteri Agama Nomor 42 Tahun 2016 (2016).

Sugiyono. (2010). ndekatan Kuantitatif, Kualitatif, dan R\&B. Bandung: Alpabeta.

Sunyoto, D. (2014). Manajemen Sumber Daya Manusia. Jakarta: CAPS (Center for Academic Publishing Service).

Uyanto, S. S. (2009). Pedoman analisis data dengan SPSS Edisi 3. Yogyakarta: Graha Ilmu.

Zainal, V. R. (2004). Manajemen Sumber Daya Manusia untuk Perusahaan dari Teori ke Praktik. Jakarta: PT RajaGrafindo Persada. 